\title{
IMPORTANCE OF RADIOGRAPHY IN ORTHOSTATISM IN THE CONDUCT OF THORACOLOMBAR TRANSITION FRACTURES
}

\author{
IMPORTÂNCIA DA RADIOGRAFIA EM ORTOSTATISMO NA CONDUTA DE FRATURAS DA \\ TRANSIÇÃO TORACOLOMBAR
}

\section{IMPORTANCIA DE LA RADIOGRAFÍA EN ORTOSTATISMO EN LA CONDUCTA DE FRACTURAS DE LA TRANSICIÓN TORACOLUMBAR}

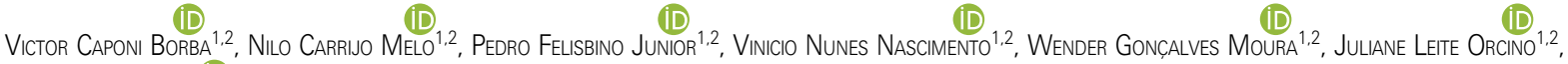 \\ MURILO TAVARES DAHER $1,2,3$ \\ 1. Centro de Reabilitação e Readaptação Dr. Henrique Santillo - CRER, Spine Service, Goiânia, GO, Brazil. \\ 2. Hospital de Urgências Governador Otávio Lage - HUGOL, Goiânia, GO, Brazil. \\ 3. Faculdade de Medicina da Universidade Federal de Goiás, Department Of Orthopedics and Traumatology - DOT/UFG, Goiânia, GO, Brazil.
}

\begin{abstract}
Objective: To evaluate the importance of radiography in the orthostatic position in the initial assessment of patients with thoracolumbar transition fractures and whether this image changes the surgical indication. Methods: Medical records and imaging tests of patients treated for thoracolumbar transition fractures from June 2018 to June 2019 were evaluated. Trauma patients between 18 and 60 years of age with fractures of T10 to L3 who had been indicated for conservative treatment were included. Cases of fractures considered unstable were excluded. Radiographs were taken with the patient in the supine position (supine X-ray), computed tomography (CT), and orthostatic radiography (orthostatic X-ray). Segmental kyphosis and degree of wedging were evaluated. The measurements were compared using the Wilcoxon test. The McNemar test was used to assess changes in conduct according to the criteria for surgical indication (kyphosis $\geq 25^{\circ}$ and wedging $\geq 50 \%$ ). Results: Fifty patients were evaluated, nine of whom (18\%) were indicated for a change of conduct according to the orthostatic examinations and were submitted to surgical treatment. Vertebral kyphosis increased by $40.6 \%$ ( $p<0.001)$. The wedging increased by $25.62 \%$ ( $p<0.0001$ ). Conclusion: Eighteen percent of the total number of patients who did not present instability criteria in radiographs in the supine position satisfied at least one of these criteria when the orthostatic X-ray was performed. Level of evidence 3B; Retrospective case series study.
\end{abstract}

Keywords: Spinal Injuries; Radiography; Patient Positioning; Kyphosis; Compression Fractures.

\section{RESUMO}

Objetivo: Avaliar a importância da radiografia em posição ortostática na avaliação inicial dos pacientes com fraturas da transição toracolombar e se essa imagem modifica a indicação cirúrgica. Métodos: Foram avaliados prontuários e exames de imagens dos pacientes atendidos com fraturas da transição toracolombar, no período de junho 2018 a junho 2019. Foram incluídos pacientes vítimas de trauma, entre 18 e 60 anos de idade, com fraturas de $T 10$ a L3, que tinham indicação de tratamento conservador. Foram excluídos os casos de fraturas consideradas instáveis já na avaliação inicial. Foram realizadas radiografias com o paciente na posição supina (Rx supino), tomografia computadorizada (TC) e radiografia ortostática (Rx ortostático). Foram avaliados a cifose segmentar e o grau de cunha. As medidas foram comparadas com o teste de Wilcoxon. Foi usado o teste de McNemar para avaliar mudanças de conduta de acordo com os critérios de indicação cirúrgica (cifose $\geq 25^{\circ}$ e cunha $\geq$ 50\%). Resultados: Foram avaliados 50 pacientes, sendo que nove (18\%) tiveram indicação de mudança de conduta de acordo com os exames ortostáticos e foram submetidos a tratamento cirúrgico. A cifose vertebral aumentou 40,6 \% ( $p<0,001)$. O grau da cunha aumentou 25,62\% ( $p$ $<0,0001$ ). Conclusões: Do total, $18 \%$ dos pacientes que não apresentavam critérios de instabilidade nas radiografias em posição supina apresentaram pelo menos um desses critérios quando se realizou o Rx ortostático. Nível de evidência 3B; Estudo série de casos retrospectivos.

Descritores: Traumatismos da Coluna Vertebral; Radiografia; Posicionamento do Paciente; Cifose; Fraturas por Compressão.

\section{RESUMEN}

Objetivo: Evaluar la importancia de la radiografía en posición ortostática en la evaluación inicial de los pacientes con fracturas de transición toracolumbar y si esa imagen modifica la indicación quirúrgica. Métodos: Fueron evaluados los historiales médicos y exámenes de imágenes de los pacientes atendidos con fracturas de la transición toracolumbar, en el período de junio de 2018 a junio de 2019 . Fueron incluidos pacientes víctimas de trauma, entre 18 y 60 años de edad, con fracturas de T10 a L3, que tenían indicación de tratamiento conservador. Fueron excluidos los casos de fracturas consideradas inestables ya en la evaluación inicial. Fueron realizadas radiografías con el paciente en posición supina (Rx supino), tomografía computarizada (TC) y radiografía ortostática (Rx ortostático). Fueron evaluadas la cifosis segmentaria y el grado de cuña. Las medidas fueron comparadas con el test de Wilcoxon. Fue usado el test de McNemar para evaluar los cambios de conducta de acuerdo con los criterios de indicación quirúrgica (cifosis $\geq 25^{\circ}$ y cuña $\geq 50 \%$ ). Resultados: Fueron evaluados 50

Study conducted at the Spine Group of the Centro de Reabilitação e Readaptação Dr. Henrique Santillo - CRER, Goiânia, GO, Brazil.

Correspondence: Murilo Tavares Daher. Rua 70, 351, apto 302, Jardim Goiás, Goiânia, GO, Brasil. 74810-350. murilodaher@uol.com.br 
pacientes, siendo que nueve (18\%) tuvieron indicación de cambio de conducta de acuerdo con los exámenes ortostáticos y fueron sometidos a tratamiento quirúrgico. La cifosis vertebral aumentó 40,6\% ( $p<0,001)$. El grado de cuña aumentó 25,62\% ( $p<0,0001)$. Conclusiones: Del total, $18 \%$ de los pacientes que no presentaban criterios de inestabilidad en las radiografías en posición supina presentaron al menos uno de estos criterios cuando se realizó el Rx ortostático. Nivel de evidencia 3B; Estudio serie de casos retrospectivos.

Descriptores: Traumatismos Vertebrales; Radiografía; Posicionamiento del Paciente; Cifosis; Fracturas por Compresión.

\section{INTRODUCTION}

Compression-type fractures of the thoracolumbar spine (type A of the AOSpine classification) correspond for the most part to injuries between T10 and L3 and there is no consensus around their management in the literature, especially when it comes to burst fractures (A3 and A4) without associated neurological deficit. ${ }^{1}$

Radiography is considered the initial examination for diagnosis, evaluation of severity, and therapeutic conduct. The treatment of these fractures is based on the anatomical aspects related to stability (wedging of the vertebral body and segmental kyphosis) and on the functional state of the patient (pain and neurological examination). In the absence of neurological deficit, protocols and objective radiographic measurements of the wedging of the vertebral body and kyphotic deformity are described in the literature to exclude fractures considered unstable, in which the posterior ligament complex may be injured and evolve with pain or deformity. ${ }^{2}$

The stability of the injury is the key point for defining the conduct and predicting results in conservative follow-up. In fractures known to be stable, treatment with orthoses allows the patient to support the load of their own body and to move early. ${ }^{3}$ However, up to now, radiography in the orthostatic positions (submitting the spine to axial loads) is not part of the initial assessment of these patients. Additionally, we know that some patients experience worsening deformity and chronic pain during long-term follow-up.

The objective of this study is to define the importance of radiography in the orthostatic position in the initial evaluation of the patient with a fracture in the thoracolumbar transition and to assess whether it implies change in the surgical indication in order to obtain an additional parameter for the evaluation of stability, particularly in fractures with questionable instability.

\section{METHODS}

Following approval by the local Institutional Review Board (IRB) (15125619.0.0000.5082), the medical records and imaging examinations of patients treated for thoracolumbar transition fractures in a tertiary center specializing in trauma during the period between June 2018 and June 2019 were evaluated. A waiver of the informed consent form was approved by the IRB due to the characteristics of the study.

Patients between 18 and 65 years of age with fractures from T10 to $L 3$ who were in conservative treatment were included. They were submitted to radiographs in the orthostatic position (orthostatic X-ray) and in decubitus (supine X-ray) and computed tomography (CT).

The orthostatic X-rays were performed in a standardized manner with the patient standing with feet together, the ray centered on the thoracolumbar transition one meter from the ampoule, with the upper limbs flexed and the hands touching the clavicle.

Patients with pathological or osteoporotic injuries or other injuries that did not allow radiographs in the orthostatic position (synergistic fractures in the lower limbs) were excluded. In addition, patients with deficits or injuries considered unstable (types B or C), as well as unstable type $A$ injuries, in the supine X-ray and CT examination were excluded. Unstable type A injuries were defined as those that presented segmental kyphotization $\geq 25^{\circ}$ and wedging of the vertebral body $\geq 50 \%$, which are the criteria classically established in the literature. ${ }^{4-6}$ Those patients had already been considered to have unstable injuries in the initial evaluation and had been referred for surgical treatment. The patients with injuries considered stable (type A fractures with wedging $<50 \%$ and kyphotization $<20^{\circ}$ ) underwent orthostatic radiography.
The clinical evaluation was conducted using the Frankel neurological scale ${ }^{7}$ and palpation of painful points in search of a palpable gap or other relevant indication leading to the suspicion of an unstable injury.

The radiographic evaluation was conducted using the following parameters: segmental kyphosis (measured in the CT/supine X-ray/ orthostatic X-ray) (Figure 1) and vertebral body wedging (measured in the CT/supine X-ray/orthostatic X-ray) (Figure 2) and (CT axial cut). (Figure 3)

Kyphotization was calculated by the Cobb angle, taking the upper plateau of the of the adjacent vertebra above the fracture and the lower plateau of the vertebra below the fracture into account, considered the best parameter for the evaluation of kyphosis secondary to ligament injury. (Figure 2A)

The percentage of wedging of the vertebral bodies is calculated by the mean height of the bodies above and below the fractured

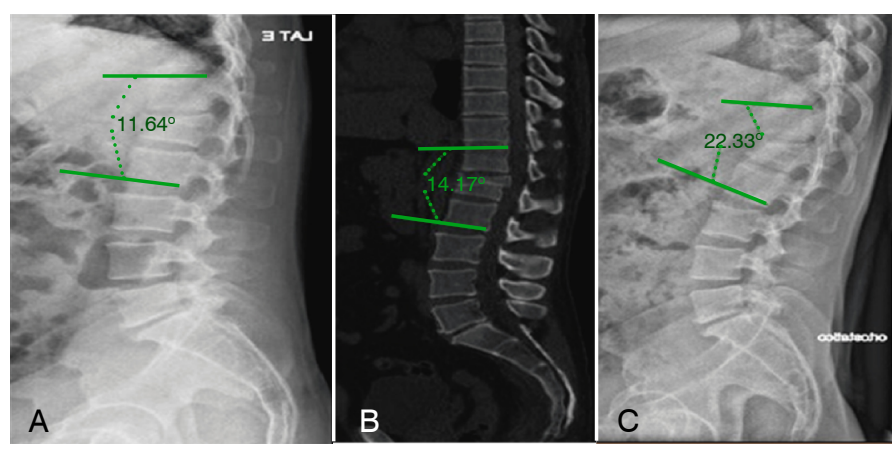

Figure 1. Segmental kyphosis measured in supine $X$-ray (A), CT sagittal cut (B), and orthostatic X-ray (C).
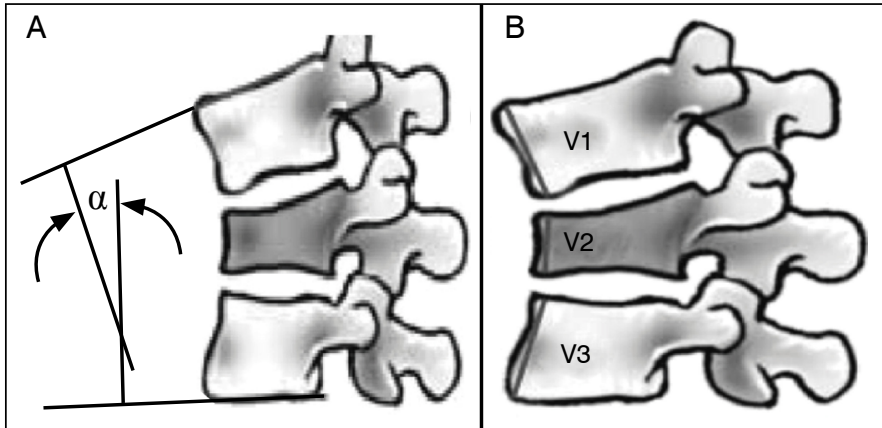

Figure 2. Method of measuring segmental kyphosis (A) and the percentage of vertebral wedging $(\mathrm{B})$.
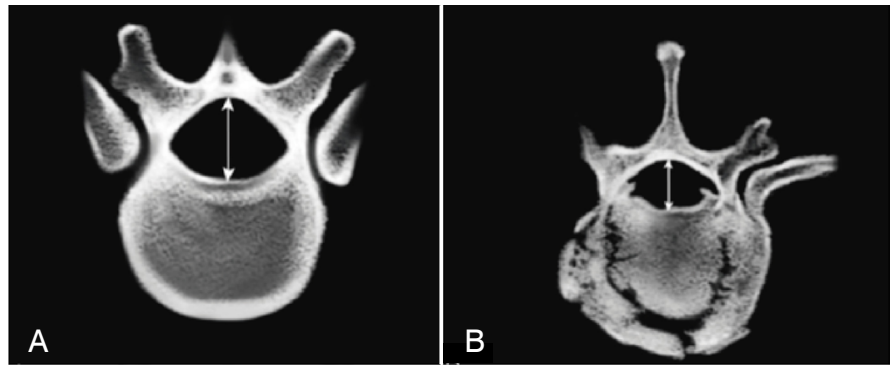

Figure 3. CT showing measurement in the adjacent level $(A)$ and in the fractured vertebra (B). 
vertebra, subtracting the height of the fractured vertebral body, divided by the mean height of the upper and lower vertebrae and multiplied by 100, according to the following formula: $\{[(\mathrm{V} 1+\mathrm{V} 3) / 2-\mathrm{V} 2] /$ $(\mathrm{V} 1+\mathrm{V} 3) / 2\} \times 100 .{ }^{8}$ (Figure $2 \mathrm{~B}$ )

All the patients were evaluated for age, the trauma mechanism, as well as specific conduct on a case-by-case basis, also assessing whether there had been any change in conduct with the execution of the orthostatic radiographs. It is a question of indirect signs of vertebral segment instability that are used in the service for surgical indication. 9,10

- Segmental kyphosis $\geq 25^{\circ}$

- Wedging $\geq 50 \%$

- Invasion of the canal $>50 \%$

Based on these measurements, we determined if there had been a worsening of kyphotization and/or vertebral wedging with the radiographs in the orthostatic position in order to change the conduct based on the instability criteria. The measurements were taken by the same examiner (VCB), a fifth-year fellow in spine surgery, and discussed with the senior author (MTD). Caresteam Vue Motion (C) software (Carestream Health, Inc., NY, NY, USA, 2019) was used in the initial patient evaluation.

All data were presented with their means and standard deviations. Continuous data, age and the radiographic measurements, were submitted to the Shapiro-Wilk test to verify distribution and they did not reflect normal distribution. The non-parametric Wilcoxon test for paired data was used to compare the radiographic measurements obtained in the supine and orthostatic positions.

We evaluated how many patients changed their conduct based on the instability criteria (kyphosis $\geq 25^{\circ}$ and wedging $\geq 50 \%$ ) using the McNemar paired measures test for categorical data. All the tests were applied accepting a probability of error of $5 \%$ and considering a confidence interval $(\mathrm{Cl})$ of $95 \%$.

\section{RESULTS}

Fifty patients with a mean age of 42.38 years $( \pm 13.13)$ were included, 32 (64\%) of whom were male and 18 (36\%) female. The most commonly fractured level was $L 1$, at 20 vertebrae (40\%), followed by level T12 at 14 vertebrae (28\%). According to the AO classification, the most common fractures were type A1, with 30 fractures $(60 \%)$ and type $A 3$, with 14 fractures $(28 \%)$. The most common trauma mechanism was the automobile accident with 28 cases (56\%), followed by fall from a height with 14 cases $(28 \%)$. All patients tolerated orthostatic radiography.

Then mean Cobb angle was $11.29^{\circ}( \pm 7.74)$ in the supine X-ray, $9.52^{\circ}( \pm 5.46)$ in the CT, and $14.81^{\circ}( \pm 7.02)$ in the orthostatic X-ray. (Table 1) There was an increase of $40.6 \%$ in segmental kyphosis and there were significant differences in the comparisons between the values obtained for the supine $\mathrm{X}$-ray, the orthostatic $\mathrm{X}$-ray, and the $\mathrm{CT}$, except in the comparison between the orthostatic $\mathrm{X}$-ray and the CT $(p=0.065)$. (Table 2)

Wedging increased by $20.29 \%( \pm 12.50)$ in the supine radiograph, $20.80 \%( \pm 12.85)$ in the CT, and $26.11 \%( \pm 16.11)$ in the orthostatic X-ray (Table 1) - a statistically significant increase of 25.62\%. (Table 2)

Nine patients $(18 \%)$ had a change in their treatment indication and were therefore treated surgically. Five (10\%) of these patients were indicated for surgical treatment after undergoing orthostatic

Table 1. Mean, standard deviation, minimum, maximum values for segmental kyphosis and vertebral wedging measured in supine X-ray, orthostatic X-ray, and CT.

\begin{tabular}{c|c|c|c|c|c|c}
\hline & \multicolumn{3}{|c|}{ Segmental Kyphosis } & \multicolumn{3}{c}{ Vertebral Wedging } \\
\hline & Mean & $\begin{array}{c}\text { Standard } \\
\text { Deviation }\end{array}$ & $\begin{array}{c}\text { Min.- } \\
\text { Max. }\end{array}$ & Mean & $\begin{array}{c}\text { Standard } \\
\text { Deviation }\end{array}$ & $\begin{array}{c}\text { Min.- } \\
\text { Max. }\end{array}$ \\
\hline Supine X-ray & $11.29^{\circ}$ & \pm 7.74 & $1^{\circ}-24^{\circ}$ & $20.29 \%$ & \pm 12.50 & $5-44 \%$ \\
\hline CT & $9.52^{\circ}$ & \pm 5.46 & $1^{\circ}-21^{\circ}$ & $20.80 \%$ & \pm 12.85 & $5-48 \%$ \\
\hline Orthostatic X-ray & $14.81^{\circ}$ & \pm 7.02 & $6^{\circ}-34^{\circ}$ & $26.11 \%$ & \pm 16.11 & $5-48 \%$ \\
\hline
\end{tabular}

X-rays that revealed a worsening of segmental kyphosis to values greater than $25^{\circ}$ (Figure 4). Four (8\%) were changed to a surgical indication due to wedging (collapse) of the vertebral body that had worsened to values greater than $50 \%$. The other patients did not have clinically significant changes of their radiographic parameters during the course of treatment.

Table 2. Comparison between the values obtained in the supine $X$-ray, orthostatic $X$-ray, and $\mathrm{CT}$, according to the Wilcoxon statistical test $(p<0.05-\mathrm{Cl} 95 \%)$

\begin{tabular}{c|c|c|c|c}
\hline & \multicolumn{2}{|c|}{ Supine X-ray } & \multicolumn{2}{c}{ Orthostatic X-ray } \\
\hline & Kyphosis & Wedging & Kyphosis & Wedging \\
\hline Supine X-ray & - & - & - & - \\
\hline Orthostatic X-ray & 0.001 & 0.0001 & - & - \\
\hline CT & 0.0001 & 0.0001 & 0.065 & 0.019 \\
\hline
\end{tabular}

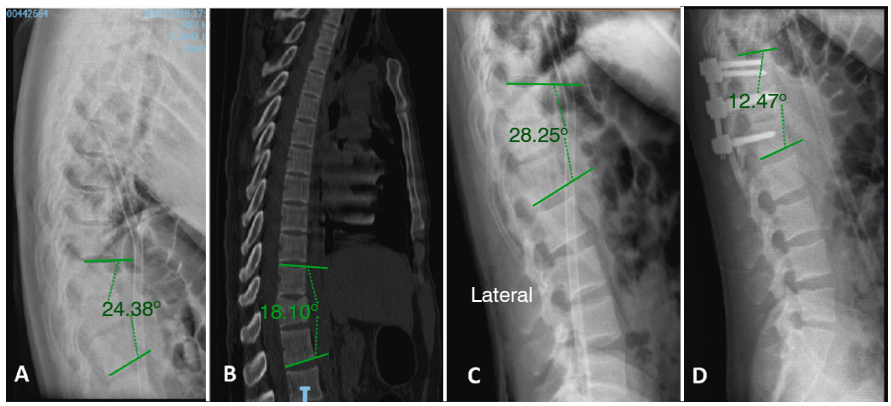

Figure 4. Male patient, 35 years of age, automobile accident victim, fracture of T12 type $A 3$ by the $A O$ classification. Supine $X$-ray (A), CT (B), and orthostatic $X$-ray (C). He presented a change of conduct with the orthostatic $X$-ray (C) due to kyphotization during follow-up to a value greater than 25 degrees. Postoperative aspect with stabilization of the fracture and improved segmental kyphosis (D).

\section{DISCUSSION}

Thoracolumbar transition injuries are common in emergency hospitals and their conduct, especially in burst fractures (A3 and A4) without neurological deficit, is still controversial. In our case series the most frequent trauma mechanisms were automobile accidents and falls from a height, mostly involving young male patients (mean age of 42 years), similar to the other studies in the literature. ${ }^{11}$

For fractures considered stable, treatment is conducted using orthoses and early mobilization. However, to date no examination in the orthostatic position with load bearing is taken into consideration in the initial patient evaluation. ${ }^{12}$

The concept of stability is much debated and classically described by White and Panjabi ${ }^{13}$ as the capacity of the spine to maintain its anatomical relationships under physiological loads. Based on this concept, we consider the importance of evaluation in orthostasis for fractures of the thoracolumbar transition and we use this resource in defining urgent care conduct. We noticed an increase in segmental kyphosis and wedging values in orthostatic as compared to supine radiographs and tomography, with some reaching values considered higher than those standardized as instability and surgical indication criteria.

Carvalho et al. ${ }^{14}$ evaluated patients with thoracolumbar burst fractures under conservative treatment observing that, during a mean period of 38 months, 19.3\% suffered from severe pain and frequent absences from work or disability. It is worth asking whether some of the cases, already at the initial assessment, were undiagnosed unstable injuries. Our study, unlike that of Carvalho et al., was conducted retrospectively but sought to use this perception to reduce the number of fractures that would evolve poorly with conservative treatment (chronic pain and worsening kyphosis).

Evaluation in decubitus (radiography and tomography) is not effective for a complete evaluation of posterior ligament instability. ${ }^{15}$ The motive behind conducting a study of only images in the supine position is questionable since conservative treatment includes orthostasis. 
Magnetic resonance has greater than 90\% accuracy for ligament injuries, but it is still difficult to access and expensive, especially in urgent care hospitals. Thus, orthostatic radiography has the great advantage of being extremely inexpensive and available in any healthcare center. ${ }^{16}$

In 2004, Mehta et al. ${ }^{17}$ reported that tomography has low sensitivity for predicting the appearance of post-traumatic deformities. In their study they took radiographs after 3 months of follow-up and observed that some patients had evolved with a worsening of deformity. Based on this observation, they postulated that orthostatic radiographs could provide some indication of the stability of the injury. Then they took weight-bearing radiographs of 28 patients with fractures between $\mathrm{T} 12$ and $\mathrm{L} 2$ and reported a change of conduct in $25 \%$ of the cases. Our study of 50 patients reached to same conclusion in relation to radiographs in the standing position.

In Brazil, Defino ${ }^{6}$ has voiced his concern with the outcomes of conservative treatment for thoracolumbar fractures, noting that radiographic and tomographic studies in the supine position are not always sufficient to identify which patients would have good or bad evolution, either from the clinical or radiographic point of view, concluding that other variables, beyond instability criteria, could influence these results.
This study has a number of limitations. It is a retrospective study of a small case series that does not assess the evolution of operated and conservatively treated patients. However, it describes an extremely simple and inexpensive way to evaluate the stability of thoracolumbar transition injuries that can be easily reproduced and applied in other centers.

\section{CONCLUSION}

Performing orthostatic radiographs for thoracolumbar fractures proved to be effective in identifying unstable lesions that were not identified by examination in the supine position in the initial evaluation. Because it is a low-cost and easy-to-perform examination in trauma centers, we routinely suggest and perform it as part of our diagnostic arsenal. In this study, a total of $18 \%$ of the patients had their conservative treatment changed to surgery.

All authors declare no potential conflict of interest related to this article.

CONTRIBUTION OF THE AUTHORS: Each author made significant individual contributions to this manuscript. VCB: writing of the manuscript, bibliographical review, and data collection. WGM, PFJ, VNN, and NCM participated in the surgeries as surgeons and assistants. MTD: conducted the entire project, presented the idea, and was the creator of the work. In addition to this, he revised the manuscript and provided guidance. JLO participated in the statistical analysis and manuscript revision.

\section{REFERENCES}

1. Magerl F, Aebi M, Gertzbein SD, Harms J, Nazarian S. A comprehensive classification of thoracic and lumbar injuries. Eur Spine J. 1994;3(4):184-201. doi: 10.1007/BF02221591

2. Siebenga J, Leferink VJ, Segers MJ, Elzinga MJ, Bakker FC, Haarman HJ, et al. Treatment of traumatic thoracolumbar spine fractures: a multicenter prospective randomized study of operative versus nonsurgical treatment. Spine (Phila Pa 1976). 2006;31(25):2881-90. doi: 10.1097/01.brs.0000247804.91869.1e

3. Ferguson RL, Allen BL Jr. A mechanistic classification of thoracolumbar spine fractures. Clin Orthop Relat Res. 1984;(189):77-88.

4. Reinhold M, Audigé L, Schnake KJ, Bellabarba C, Dai LY, Oner FC. AO spine injury classification system: a revision proposal for the thoracic and lumbar spine. Eur Spine J. 2013;22(10):2184-201. doi:10.1007/s00586-013-2738-0

5. Linn M, Kim CW, Valente M. Compression fractures of the thoracic and lumbar spine. In: Zigler JE, Eismont FJ, Garfin SR, Vaccaro AR. Spine Trauma. Rosemont: American Academy of Orthopaedic Surgeons; 2011. p. 499-514.

6. Defino HLA, Fuentes AER, Remondi PH, Vallim EC. Tratamento conservador das fraturas da coluna toracolombar. Rev Bras Ortop. 2000;35(8):301-8.

7. Frankel HL, Hancock DO, Hyslop G, Melzak J, Michaelis LS, Ungar GH, et al. The value of postural reduction in the initial management of closed injuries of the spine with paraplegia and tetraplegia. Paraplegia. 1969;7(3):179-92. doi: 10.1038/sc.1969.30

8. Keynan O, Fisher CG, Vaccaro A, Fehlings MG, Oner FC, Dietz J, et al. Radiographic Measurement Parameters in Thoracolumbar Fractures: A Systematic Review and Consensus Statement of the Spine Trauma Study Group. Spine (Phila Pa 1976). 2006;31(5):E156-65. doi: 10.1097/01.brs.0000201261.94907.0d
9. Keene JS, Lash EG, Kling TF Jr. Undetected posttraumatic instability of "stable" thoracolum bar fractures. J Orthop Trauma. 1988;2(3):202-11.

10. Garcia EB, Silva AL, Pimenta LG, Cunha FM, Garcia EB, Gonçalves RG, et al. Fratura da coluna toracolombar do tipo explosão em T12/L1/L2. Rev Bral Ortop. 2002;37(10):445-53.

11. Avanzi O, Chih LY, Meves R, Caffaro MFS, Bueno RS, Freitas MMF. Fratura toracolombar tipo explosão: resultados do tratamento conservador. Rev Bras Ortop. 2006:41(4):109-15.

12. Cantor JB, Lebwohl NH, Garvey T, Eismont FJ. Nonoperative management of stable thoracolumbar burst fractures with early ambulation and bracing. Spine (Phila Pa 1976) 1993;18(8):971-6. doi: 10.1097/00007632-199306150-00004

13. White AA, Panjabi MM. Clinical biomechanics of the spine, $2^{\text {nd }}$ ed. Philadelphia: Lippincott Williams \& Wilkins; 1990; 30-643.

14. Carvalho AD, Meves R, Rezende R, Caffaro MFS, Landim E, Avanzi O. Tratamento conservador da fratura toracolombar explosão e Classificação de McComack. Acta ortop. bras. 2011;19(4):206-9. doi:10.1590/S1413-78522011000400007

15. Petersilge CA, Pathria MN, Emery SE, Masaryk TJ. Thoracolumbar burst fractures: evaluation with MR imaging. Radiology. 1995;194(1):49-54. doi: 10.1148/radiology.194.1.7997581

16. Haba H, Taneichi H, Kotani $Y$, Terae S, Abe S, Yoshikawa H, et al. Diagnostic accuracy of magnetic resonance imaging for detecting posterior ligamentous complex injury associated with thoracic and lumbar fractures. J Neurosurg. 2003:99(1Suppl):20-6. doi: 10.3171/ spi.2003.99.1.0020

17. Mehta JS, Reed MR, McVie JL, Sanderson PL. Weight-bearing radiographs in thoracolumbar fractures: do they influence management? Spine (Phila Pa 1976). 2004;29(5):564-7. doi: 10.1097/01.brs.0000113873.07484.5d 